Article

\title{
Optimization of UV-C Processing of Donkey Milk: An Alternative to Pasteurization?
}

\author{
Photis Papademas*(D), Panagiotis Mousikos (D) and Maria Aspri (D) \\ Dairy Science and Technology, Department of Agricultural Sciences Biotechnology and Food Science, \\ Cyprus University of Technology, 3036 Limassol, Cyprus; panagiotis.mousikos@cut.ac.cy (P.M.); \\ maria.aspri@cut.ac.cy (M.A.) \\ * Correspondence: photis.papademas@cut.ac.cy
}

\section{check for}

updates

Citation: Papademas, P.; Mousikos, P.; Aspri, M. Optimization of UV-C Processing of Donkey Milk: An Alternative to Pasteurization? Animals 2021, 11, 42. https://doi.org/ 10.3390/ani11010042

Received: 16 October 2020

Accepted: 17 December 2020

Published: 28 December 2020

Publisher's Note: MDPI stays neutral with regard to jurisdictional claims in published maps and institutional affiliations.

Copyright: () 2020 by the authors. Licensee MDPI, Basel, Switzerland. This article is an open access article distributed under the terms and conditions of the Creative Commons Attribution (CC BY) license (https: / creativecommons.org/ licenses/by/4.0/).
Simple Summary: Donkey milk has received much interest lately due to its chemical composition, which is very close to human milk as well as to its unique functional properties (antibacterial, antioxidant, immunomodulatory, and antitumor activities). Furthermore, donkey milk is considered a valid alternative milk for infants and adults suffering from cow milk protein allergy. However, it is recommended by pediatricians and clinicians that raw donkey milk must be thermally processed to render it safe for sensitive population (i.e., infants and immunocompromised). On the other hand, thermal processing is known to reduce the bioactivity of milk. Consequently, the objective of this study is to determine the feasibility of the UV-C system to inactivate or reduce foodborne pathogens in raw donkey milk in order to produce a safe, non-thermally processed donkey milk that can be consumed by special population groups (infants, elderly, immunocompromised). Results obtained from this study indicate that UV-C has the potential to be used as a non-thermal treatment to reduce food borne pathogens present in raw donkey milk.

Abstract: The effect of UV-C light technology on the inactivation of six foodborne pathogens inoculated in raw donkey milk was evaluated. Fresh raw donkey milk was artificially inoculated with the following foodborne pathogens-L. inoccua (NCTC 11288), S. aureus (NCTC 6571), B. cereus (NCTC 7464), Cronobacter sakazakii (NCTC 11467), E. coli (NCTC 9001), Salmonella enteritidis (NCTC 6676) - and then treated with UV-C doses of up to $1300 \mathrm{~J} / \mathrm{L}$. L. innocua was the most UV-C-resistant of the bacteria tested, requiring $1100 \mathrm{~J} / \mathrm{L}$ for complete inactivation, while the rest of the bacteria tested was destructed in the range of 200-600 J/L. Results obtained from this study indicate that UV-C light technology has the potential to be used as a non-thermal processing method for the reduction of spoilage bacteria and foodborne pathogens that can be present in raw donkey milk.

Keywords: donkey milk; UV-C technology; non-thermal methods; microbial inactivation; milk pathogens

\section{Introduction}

In recent years, there has been a growing interest for donkey milk production and commercialization due to its similar composition with human milk, making it ideal for consumption by sensitive population groups such as infants with cow milk protein allergy (CMPA), the immunocompromised, and the elderly [1]. According to the literature, raw donkey milk has a low total bacterial count; nevertheless, the presence of foodborne pathogens such as E. coli 0157, S. aureus, Campylobacter spp., and Cronobacter sakazaki was also detected [2-5]. Therefore, raw donkey milk is subjected to thermal pasteurization in order to ensure its microbiological safety and to comply with the European Community Regulation 853/2004. However, the method has many drawbacks such as high energy cost, and it may influence protein denaturation, deterioration of the technological properties of milk (e.g., prolong enzymatic milk protein coagulation) and loss of nutrients, which is associated with flavor degradation. Thus, there is an interest for alternative methods that 
would ensure the microbiological safety of the milk while preserving its high biological value. UV-C light technology can be used as an alternative non-thermal method.

Ultraviolet light (UV-C) treatment is one of the most promising non-thermal technologies to destruct microorganisms in milk without involving heat [6-16]. UV technology has the advantage over thermal pasteurization of its ability to minimize the loss of flavors and nutrients, and it is more energy efficient. A limitation of UV-C light processing of milk is its ability to penetrate into opaque liquids resulting in no or very low microbial inactivation [17]. Therefore, a strategy to increase the penetration is the use of turbulent flow reactors so that liquid foods are exposed to UV light uniformly.

UV radiation covers part of the electromagnetic spectrum in the range of 100-400 nm, which is categorized into three ranges based on their photochemical propertied and biological effects: UV-A (315-400 nm), UV-B (280-315 nm), and UV-C (200-280 nm) [6,18]. Microbial inactivation from UV light is associated with photochemical changes that take place in proteins and nucleic acids within the cell membrane when UV light is absorbed by the food during UV-C treatment. Photons interact with thymine and cystine nucleoside bases, causing the formation of cross-linked photoproducts, especially cyclobutyl pyrimidine dimers (CPD), which disrupt the DNA transcription, translation, and replication processes that lead to the loss of microbial cell functions and ultimately to cell death of the microorganism [18,19]. The UV-C light, in particular the wavelength range 250-260 nm, has optimal properties for the inactivation of bacteria, yeast, bacterial spores, molds, and viruses and is most widely used in the food processing industry [10].

The objective of this study was to determine the feasibility of a continuous UV-C system to inactivate or reduce foodborne pathogens that were artificially inoculated in raw donkey milk compared to the conventional pasteurization process.

\section{Materials and Methods}

\subsection{Collection of Milk Samples}

Milk samples were collected from the "Golden Donkeys Farm", located in Larnaca district, Cyprus. All donkeys were fed the same diet consisting of hay, barley, corn, and a concentrate of minerals, vitamins, and salt following the European Directive 98/58/EC. Donkeys were healthy, and no antibiotics were administrated prior to sampling. The process of milking was carried out in the stable, and donkeys were milked manually from the same milker. During milking, the udder was cleaned using sterile wet wipes and the nipples using $70 \%$ ethanol and dried with sterile gauze. Sampling for microbiological and physicochemical analysis was conducted weekly (33 weeks) from October of 2018 until May 2019 from the daily milk batch (20 L from 20-25 milking donkeys). The donkey milk samples were collected in sterilized containers $(250 \mathrm{~mL})$, placed in cool-boxes, and transported to the laboratory $\left(4^{\circ} \mathrm{C}\right)$ and processed during the same working day for physicochemical and microbiological analysis. These 33 samples were used to assess the general microbiological quality of raw donkey milk.

For the UV-C and pasteurization experiments, three batches of $7 \mathrm{~L}$ donkey milk samples were collected as described above. The initial background flora of the raw milk was assessed each time before subsequent inoculation and processing (UV-C or pasteurization) by serial dilutions in saline solution. A series of dilutions were pour plated in duplicate on Plate Count Agar, and the plates were incubated at $30^{\circ} \mathrm{C}$ for $72 \mathrm{~h}$.

\subsection{Bacterial Strains}

All strains were obtained from National Collection of Type Cultures (NCTC). L. inoccua (NCTC 11288), S. aureus (NCTC 6571), B. cereus (NCTC 7464), Cronobacter sakazakii (NCTC 11467), E. coli (NCTC 9001), and Salmonella enteritidis (NCTC 6676) were reconstituted and growth at $37^{\circ} \mathrm{C}$ in brain heart infusion (BHI) broth. All cultures were stored in glycerol $\left(20 \% \mathrm{vol} / \mathrm{vol}\right.$ ) at $-80{ }^{\circ} \mathrm{C}$ until use. The selection of the above pathogens was based on the fact that these are the main foodborne pathogens associated with milk and dairy products contamination. Moreover, B. cereus is a Gram-positive spore-forming bacterium that is 
capable of surviving pasteurization temperatures, while Cronobacter sakazakii has been mainly isolated from dried infant formula, and also, both strains has been previously isolated from raw donkey milk [3]. Therefore, the selection of the above strains was based on the future applications of this study, which is the production of a UV-C freeze-dried donkey milk powder and also taking into account the main target group of consumers (i.e., infants, immunocompromised, and the elderly).

\subsection{Growth of Bacterial Strains and Milk Inoculation}

To determine the log reduction capability of UV-C and pasteurization treatments, raw donkey milk samples were artificially inoculated with a cocktail of the above bacterial strains at a final concentration of approximately $5 \log \mathrm{CFU} / \mathrm{mL}$. Fresh overnight cultures of all the strains were added directly to donkey milk $(7 \mathrm{~L})$ and mixed for $5 \mathrm{~min}$. After $5 \mathrm{~min}$, $500 \mathrm{~mL}$ of the artificially inoculated raw donkey milk was placed into a beaker to be used for the pasteurization experiment. Background populations of the pathogens mentioned above were not detected in donkey milk samples prior to inoculation.

\subsection{UV-C Processing of Artificially Contaminated Raw Donkey Milk}

Ultraviolet treatment of artificially inoculated donkey milk $(7 \mathrm{~L})$ was performed in a pilot-scale, low-power UV unit designated SP-1 (SurePure) (Figure 1). The unit contained a UV bulb enclosed in an optically pure quartz sleeve that separates milk from the light

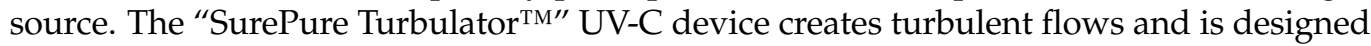
for continuous flow inactivation of turbid fluids such as milk. The SP-1 unit was operated at a flow rate of $4000 \mathrm{~L} / \mathrm{h}(1.11 \mathrm{~L} / \mathrm{s})$. The following UV doses were used: 0, 91.8, 275.4, $459,642.6,826.2,1000.8,1100,1200$, and $1300 \mathrm{~J} / \mathrm{L}$. The ultraviolet light intensity at the surface of the quartz sleeve was $17.7 \mathrm{~mW} / \mathrm{cm}^{2}$ according to the UV lamp manufacturer. According to manufacturer specifications, the turbulator had a unit area of $A=7.85 \times 104 \mathrm{~m}^{2}$ $(\mathrm{d} 1=24.5 \mathrm{~mm}, \mathrm{~d} 2=40 \mathrm{~mm}$, where $\mathrm{d} 1$ and $\mathrm{d} 2$ are the inner and outer diameters, respectively of the turbulator), a volume of $0.675 \mathrm{~L}$, and residence time of $0.608 \mathrm{~s}$ in a single unit. Therefore, at a flow rate of $4000 \mathrm{~L} / \mathrm{h}, 25.2 \mathrm{~s}$ are required for $7 \mathrm{~L}$ of donkey milk to pass through the reactor once; thus, one turn of the product through the system is equivalent to a UV-C dose of $22.95 \mathrm{~J} / \mathrm{L}$. The UV dosage per L of donkey milk treated for one reactor with continuous flow was calculated as follows: Dosage $=$ Total UV-C output per unit $(\mathrm{W}) /$ Flow rate $(\mathrm{L} / \mathrm{s})$ $=25.50 \mathrm{~W} / 1.11 \mathrm{~L} / \mathrm{s}=(25.50 \mathrm{~J} / \mathrm{s}) /(1.11 \mathrm{~L} / \mathrm{s})=22.95 \mathrm{~J} / \mathrm{L}$. Moreover, the UV dosage per surface area for one reactor was calculated as follows: UV dosage per area $=\mathrm{UV}$ intensity (I) on the surface of the sleeve $\times$ residence time $(t) ; 17.7 \mathrm{~mW} / \mathrm{cm}^{2} \times 0.608 \mathrm{~s}=10.75 \mathrm{~mJ} / \mathrm{cm}^{2}$. Samples $(50 \mathrm{~mL})$ were taken from an aseptic sampling port at specific time points corresponding to each UV dose in order to assess the microbial reduction. The SP-1 UV system was cleaned and sanitized after each use with a clean-in-place process. The process was repeated three times.

\subsection{Donkey Milk Pasteurization (Control)}

A subsample of $500 \mathrm{~mL}$ of the artificially inoculated raw donkey milk to be used for UV-C treatment was placed into a glass beaker with a magnetic stirrer and heated on a hotplate. A thermometer was immersed into the milk to monitor the temperature during the pasteurization process. Heat treatment has been carried out at $62.5^{\circ} \mathrm{C}$ for $30 \mathrm{~min}$, which is the gold standard treatment of a (milder) heat processing of donor human milk [20]. After pasteurization, the donkey milk was quickly cooled down in an ice bath until the temperature reached $4{ }^{\circ} \mathrm{C}[21]$.

\subsection{Microbiological Analysis}

UV-C treated, pasteurized, and untreated (milk before inoculation of target organisms) donkey milk samples were 10-fold diluted and spread or pour plated in duplicate on the appropriate media and incubated at specific conditions for each bacterial strain, as shown in Table 1. 


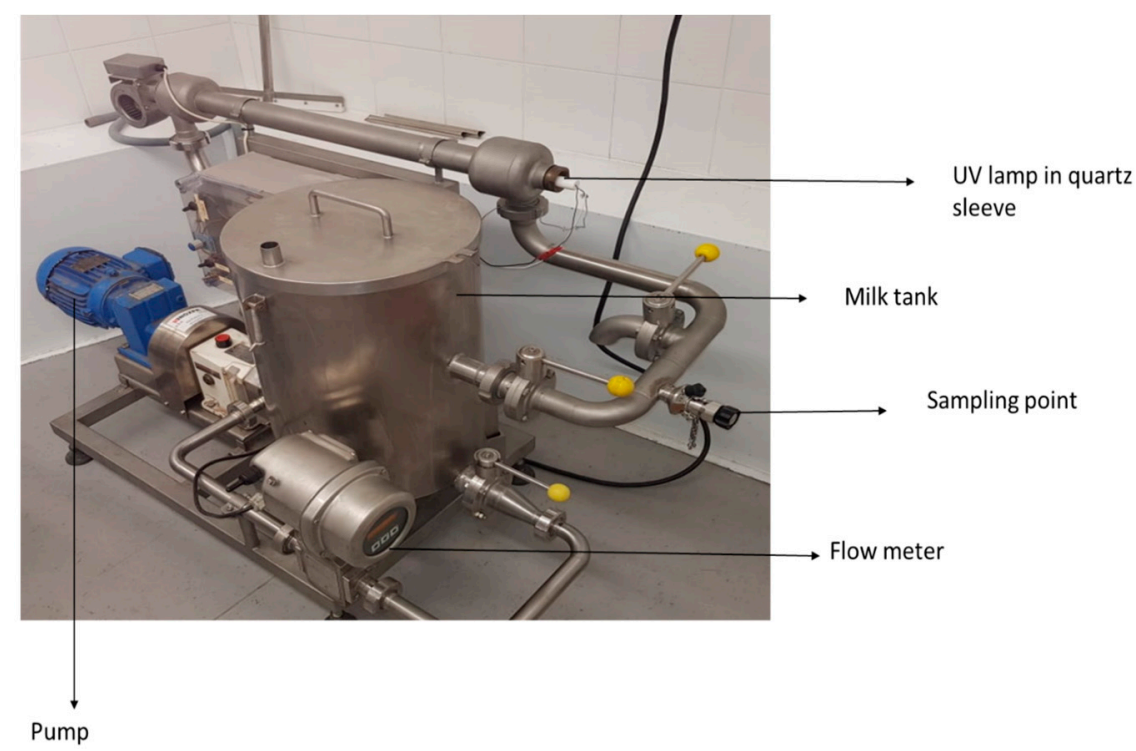

Figure 1. SurePure SP1 UV system.

Table 1. Bacterial growth conditions.

\begin{tabular}{llll}
\hline Microbiological Parameter & Microbiological Media & $\begin{array}{l}\text { Incubation } \\
\text { Conditions }\end{array}$ & Reference \\
\hline S. aureus NCTC6571 & Baird Parker & $37^{\circ} \mathrm{C} / 48 \mathrm{~h}$ & ISO 6888-1:1999 \\
L. inoccua NCTC 11288 & ALOA & $37^{\circ} \mathrm{C} / 48 \mathrm{~h}$ & ISO 11290-2:2017 \\
B. cereus NCTC 7464 & MYP & $30^{\circ} \mathrm{C} / 48 \mathrm{~h}$ & ISO 7932:2004 \\
E. coli NCTC 9001 & TBX & $44^{\circ} \mathrm{C} / 24 \mathrm{~h}$ & ISO 16649-2:2001 \\
Salmonella enteritis NCTC 6676 & Chromogenic Salmonella & $37^{\circ} \mathrm{C} / 48 \mathrm{~h}$ & ISO 6579-1:2017 \\
Cronobacter sakazakii NCTC 11467 & Chromogenic & $44^{\circ} \mathrm{C} / 24 \mathrm{~h}$ & ISO 22964:2017 \\
\hline
\end{tabular}

For higher UV dosage, undiluted samples were spread plated (1 $\mathrm{mL}$ across 3 plates) on appropriate agar for more precise microbial counts. The colonies were counted to determine the colony-forming units per milliliter. Following incubation, CFUs from triplicate plates were counted. In order to determine the reduction in bacterial number during UV-C treatment, $\mathrm{CFU} / \mathrm{mL}$ values were averaged and converted into logarithmic units because the dairy microbiological date does not usually follow a normal distribution.

\subsection{Lethality Calculations}

Microbial counts $(\mathrm{cfu} / \mathrm{mL})$ were converted to $\log 10$ and then plotted as a function of UV-C dose.

Mathematical models used to explain the inactivation kinetics of microorganisms were analyzed by a freeware add-in GInaFiT (version 1.6) using Microsoft Excel 2010 [22]. Results were the mean of three different batches. For each pathogen, three inactivation models were tested (Table 2).

The goodness of the fit of each model was evaluated using the values of higher regression coefficient $\left(R^{2}\right)$, and the lower root mean square error (RMSE). GInaFiT also provides the parameter $4 \mathrm{D}$, which is defined as the treatment dose necessary to inactivate $99.99 \%$ of the microbial population. 
Table 2. Microbial inactivation models.

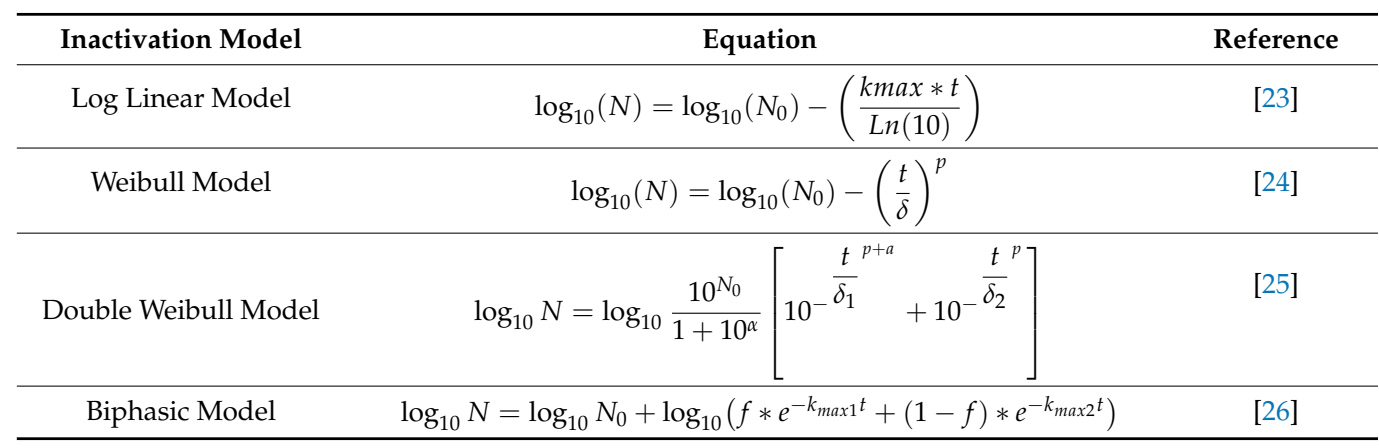

\section{Results}

The average initial concentration of the foodborne pathogens inoculated into the donkey milk ranged from 4.7 to $5.5 \log$ CFU / mL. None of the foodborne pathogens were detected in any of the donkey milk samples prior to inoculation, while the average total viable count (TVC) was $2.7 \log \mathrm{CFU} / \mathrm{mL}$. Results showed that sensitivity of foodborne pathogens to UV-C light can vary significantly among genera (Figure 2). Microbial counts of bacteria decreased as the cumulative dose of UV-C light increases. Among the tested organisms, L. inoccua proved to be the most resistant to UV-C treatment. S. enterica, B. cereus, E. coli, and Cronobacter sakazakii reacted similarly to exposure to UV-C irradiation and required similar dosages to obtain a $5-\log 10$ reduction, while $S$. aureus required $459 \mathrm{~J} / \mathrm{L}$ for complete inactivation. At a UV-C irradiation dose of $1100 \mathrm{~J} / \mathrm{L}$, no bacterial growth was observed for all the tested strains. Moreover, results of the physicochemical and microbiological quality of raw donkey milk as sampled for a period of 33 weeks are presented in Table 3. Heat treatment of artificially inoculated donkey milk at $62.5^{\circ} \mathrm{C}$ for $30 \mathrm{~min}$ was able to reduce the population of foodborne pathogens to not detectable levels.

Table 3. Microbiological and chemical quality of raw donkey milk $(\mathrm{n}=33)$.

\begin{tabular}{ccccc}
\hline Microbiological Parameters $(\log \mathbf{c f u} / \mathbf{m L})$ & Min & Max & Mean & SD \\
\hline TVC & 2.90 & 5.10 & 3.80 & 0.02 \\
Enterobacteriaceae & $<1.00$ & 3.40 & 1.90 & 0.04 \\
Staphylococcus & $<1.00$ & 4.70 & 3.10 & 0.06 \\
E. coli & $<1.00$ & $<1.00$ & $<1.00$ & $<1.00$ \\
Bacillus cereus & $<1.00$ & $<1.00$ & $<1.00$ & $<1.00$ \\
Listeria monocytogenes & ND & ND & ND & ND \\
\hline \multicolumn{2}{c}{ Chemical Parameters (g/100 $\mathbf{~ m L ) ~}$} & & \\
Fat & 0.30 & 1.40 & 0.84 & 0.07 \\
Total Solids & 1.30 & 1.96 & 1.62 & 0.05 \\
\hline
\end{tabular}

The survival data of all foodborne pathogens used in the study after each UV-C dose were adjusted to different linear and nonlinear models of survival curves (linear, Weibull, biphasic) using the GInaFiT software (Microsoft ${ }^{\circledR}$ Excel). As previously mentioned, the root mean square error (RMSE) and the $\mathrm{R}^{2}$ value were used to determine the fitting accuracy. Therefore, using the RMSE and $\mathrm{R}^{2}$ values calculated for each inactivation kinetic model as an indicator of goodness of fit, the biphasic model was the best fit for the UV-C inactivation data for L. inoccua and Cronobacter sakazakii, while the double Weibull model was the best fit for S. aureus, B. cereus, E. coli, and Salmonella enteritis (Table 4). 

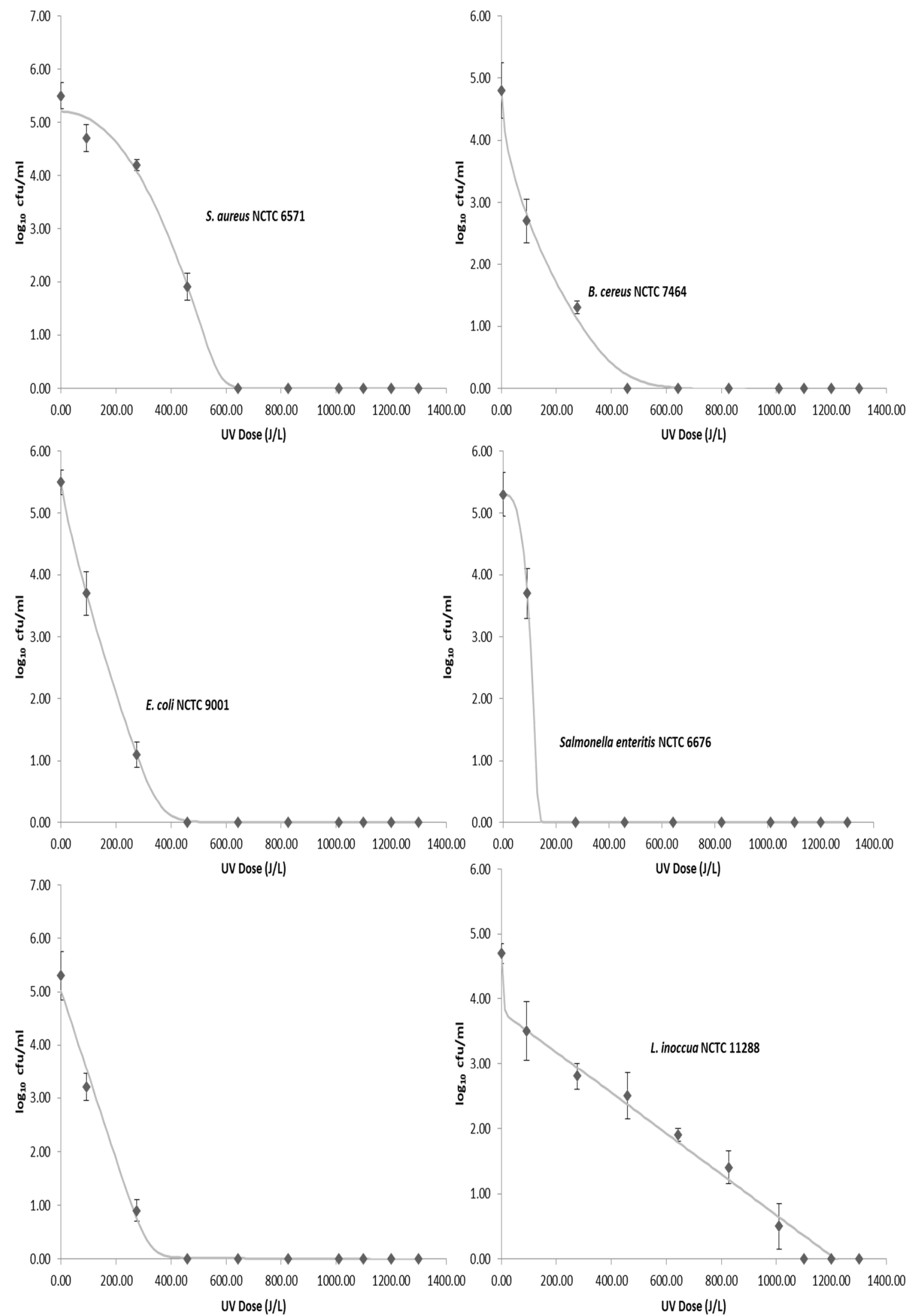

Figure 2. Survival curves for each pathogen. Points are the mean value and error bars represent standard deviation. The lines represent the inactivation model generated using the GInaFit software. 
Table 4. Root mean square error (RMSE) and R2 measures for each pathogen using different inactivation models.

\begin{tabular}{ccccccccc}
\hline Inactivation Model & \multicolumn{2}{c}{ Log Linear } & \multicolumn{2}{c}{ Weibull } & \multicolumn{2}{c}{ Double Weibull } & \multicolumn{2}{c}{ Biphasic } \\
\hline Bacteria & RMSE & $\mathbf{R}^{\mathbf{2}}$ & RMSE & $\mathbf{R}^{\mathbf{2}}$ & RMSE & $\mathbf{R}^{\mathbf{2}}$ & RMSE & $\mathbf{R}^{\mathbf{2}}$ \\
\hline S. aureus & 1.00 & 0.83 & 0.94 & 0.87 & 0.21 & 0.99 & 0.42 & 0.98 \\
\hline L. inoccua & 0.32 & 0.97 & 0.27 & 0.98 & 0.29 & 0.98 & 0.23 & 0.99 \\
\hline B. cereus & 1.25 & 0.50 & 0.83 & 0.80 & 0.12 & 0.99 & 0.30 & 0.98 \\
\hline E. coli & 1.30 & 0.61 & 0.85 & 0.85 & 0.0096 & 1.00 & 0.11 & 0.99 \\
\hline Salmonella enteritis & 1.43 & 0.52 & 1.27 & 0.67 & 0.0008 & 1.00 & 0.12 & 0.99 \\
\hline Cronobacter sakazakii & 1.25 & 0.59 & 0.96 & 0.78 & 0.64 & 0.92 & 0.20 & 0.99 \\
\hline
\end{tabular}

Moreover, in this study, the UV-C dose necessary to reduce $4 \log \mathrm{CFU} / \mathrm{mL}$ (4D) of the initial bacterial populations was calculated using the best fit inactivation model for each foodborne pathogen (Table 5).

Table 5. $4 \mathrm{D}$ values for each pathogen using the best fit inactivation model.

\begin{tabular}{ccc}
\hline Pathogen & Inactivation Model & 4D Value (J/L) \\
\hline S. aureus & Double Weibull & 507 \\
\hline L. inoccua & Biphasic & 1001 \\
\hline B. cereus & Double Weibull & 338 \\
\hline E. coli & Double Weibull & 247 \\
\hline Salmonella enteritis & Double Weibull & 130 \\
\hline Cronobacter sakazakii & Biphasic & 260 \\
\hline
\end{tabular}

\section{Discussion}

The UV-C system (turbulent flow) used in this study was able to reduce the bacterial population to not detectable levels by ensuring that the total volume of donkey milk is exposed to the surface of the light source. A mixture of different bacterial strains was inoculated into raw donkey milk in order to test the validity of UV-C, which is more representative of the multi-strain nature of microbial contamination in milk [27]. The SurePure UV-C system used in this study was also used in similar studies, and it was proven that is able to reduce pathogens and spoilage flora present in milk, fruit juices, and wine $[10,12,15,28,29]$. The fact that between studies, different parameters are present such as (a) type of UV-C equipment employed, (b) bacterial species, (c) processing conditions, and (d) physical properties of the matrices make it difficult to compare results.

A study carried out by [12] showed that the exponential reduction had a high correlation with the applied UV-C dosage. Moreover, the decimal reduction dosage for E. coli, B. cereus, and S. aureus was between 594 and $640 \mathrm{~J} / \mathrm{L}$, which is a little bit higher than the UV-C dosage found in this study. However, this difference may be due to the different UV-C equipment and bacterial cultures used in both studies. Moreover, the amount of total solids can also affect the UV-C efficiency. The human milk used in [12] study has a total solid concentration of $10.5-14.5 \mathrm{~g} / 100 \mathrm{~mL}$, which is higher than that of donkey milk $(9.23 \pm 0.29 \mathrm{~g} / 100 \mathrm{~mL})$.

Regarding L. monocytogenes, several authors $[6,7,9,10,28,30]$ have shown that it is more UV resistant when compared to other foodborne pathogens inoculated in milk, which is accordance with the results of this study. This fact can be attributed to the thicker peptidoglycan cell wall of Gram + ve bacteria in comparison to Gram -ve bacteria, which can hinder the penetration of UV photons within bacterial cells as well as to the ability of L. monocytogenes to cope with DNA damages by having a more efficient DNA repair mechanism in 
comparison to other foodborne pathogens such as E. coli [31-33]. For instance, [7,10,30] showed that for a 5-log reduction of L. monocytogenes in Ultra High Temperature (UHT) full-fat milk, a UV-C dose of $2000 \mathrm{~J} / \mathrm{L}$ is required, while $[7,10,30]$ reported that a UV dose of $15.8 \mathrm{~mJ} / \mathrm{cm}^{2}$ led to more than $5 \mathrm{log}$ reduction in L. monocytogenes in goat milk. The UV-C dose required for the reduction of L. monocytogenes by $5 \log$ was slightly higher that the UV-C dose found in this study. This could be due to the differences in composition of donkey milk, goat, and bovine milk in terms of fat and total solids.

Mathematical models that accurately explain the inactivation kinetics of foodborne pathogens in donkey milk may assist in the successful implementation of UV-C technology at the industrial level, as well as on the understanding the effect of a number of factors that should be taken into account for process optimization [34,35]. The results of the inactivation studies are in agreement with previous studies that showed that the inactivation of microorganisms do not follow first-order kinetics, especially for non-thermal processes $[10,34,36]$. The mixed Weibull model assumes the existence of two subpopulations-a more sensitive and a more resistant-while biphasic inactivation curves result from a microorganism with heterogeneous resistance to the inactivating agent [10]. The initial rapid decrease in population demonstrates the death of the less resistant strain, while the second part of the biphasic curve represents the death of resistant strains [27].

In addition, the calculation of $\mathrm{D}$ value can be of great importance for food industries planning to use UV-C technology in order to evaluate the necessary UV-C dose for the inactivation of microorganisms. However, in most cases using UV-C, inactivation kinetics of microorganisms do not follow first order, hence making it difficult to estimate the D-value required to reduce $90 \%$ of the microbial population.

\section{Conclusions}

In summary, this is a primary study demonstrating that UV-C treatment could offer an effective alternative to pasteurization in order to reduce the bacterial population of donkey milk to acceptable limits. The results showed that UV-C was effective in reducing the microbial population in the artificially contaminated donkey milk. Nevertheless, further studies are underway to investigate the effect of UV-C treatment on the biologically active components such as immunoglobulins, lactoferrin, and lysozyme as well as on vitamins (i.e., vitamins $C$ and D). Additionally, the effect on the digestibility and bioavailability of nutrients that processing has on the in vitro digesta of milk samples will be evaluated. Finally, peripheral blood mononuclear cell lines will be utilized in order to assess any effect that donkey milk digesta (and the type of processing) has on stimulating cells (i.e., cytokines) responsible for any immune-regulating effect.

Author Contributions: Conceptualization, P.P.; Methodology, P.P., M.A.; Validation, M.A., P.M.; Formal analysis, M.A.; Investigation, M.A., P.M.; Resources, P.P.; Data curation, P.P.; Writing—original draft Preparation, M.A.; Writing-review and editing, P.P., M.A.; Visualization, M.A.; Supervision, P.P.; Project administration, P.M.; Funding acquisition, P.P. All authors have read and agreed to the published version of the manuscript.

Funding: The project "Deliver" (Enterprises/0916/0083) is funded by the Research and Innovation Foundation, Cyprus.

Institutional Review Board Statement: Not applicable.

Informed Consent Statement: Not applicable.

Acknowledgments: The authors wish to acknowledge Golden Donkeys Farm, Cyprus for providing donkey milk samples.

Conflicts of Interest: The authors declare no conflict of interest. 


\section{References}

1. Souroullas, K.; Aspri, M.; Papademas, P. Donkey milk as a supplement in infant formula: Benefits and technological challenges. Food Res. Int. 2018, 109, 416-425. [CrossRef] [PubMed]

2. Martini, M.; Salari, F.; Altomonte, I.; Ragona, G.; Piazza, A.; Gori, R.; Casati, D.; Brajon, G. Effects of pasteurization and storage conditions on donkey milk nutritional and hygienic characteristics. J. Dairy Res. 2018, 85, 445-448. [CrossRef] [PubMed]

3. Conte, F.; Panebianco, A. Potential hazards associated with raw donkey milk consumption: A review. Int. J. Food Sci. 2019. Available online: https:/ / doi.org/10.1155/2019/5782974 (accessed on 24 December 2020).

4. Mottola, A.; Alberghini, L.; Giaccone, V.; Marchetti, P.; Tantillo, G.; Di Pinto, A. Microbiological safety and quality of Italian donkey milk. J. Food Saf. 2018, 38, e12444. [CrossRef]

5. Faccia, M.; D'Alessandro, A.G.; Summer, A.; Hailu, Y. Milk products from minor dairy species: A review. Animals 2020, 10, 1260. [CrossRef]

6. Bintsis, T.; Litopoulou-Tzanetaki, E.; Robinson, R.K. Existing and potential applications of ultraviolet light in the food industry-a critical review. J. Sci. Food Agric. 2000, 80, 637-645. [CrossRef]

7. Matak, K.; Churey, J.; Worobo, R.; Sumner, S.; Hovingh, E.; Hackney, C.; Pierson, M. Efficacy of UV light for the reduction of Listeria monocytogenes in goat's milk. J. Food Prot. 2005, 68, 2212-2216. [CrossRef]

8. Rossitto, P.; Cullor, J.S.; Crook, J.; Parko, J.; Sechi, P.; Cenci-Goga, B. Effects of UV irradiation in a continuous turbulent flow UV reactor on microbiological and sensory characteristics of cow's milk. J. Food Prot. 2012, 75, 2197-2207. [CrossRef]

9. Cappozzo, J.C.; Koutchma, T.; Barnes, G. Chemical characterization of milk after treatment with thermal (HTST and UHT) and nonthermal (turbulent flow ultraviolet) processing technologies. J. Dairy Sci. 2015, 98, 5068-5079. [CrossRef]

10. Crook, J.A.; Rossitto, P.V.; Parko, J.; Koutchma, T.; Cullor, J.S. Efficacy of ultraviolet (UV-C) light in a thin-film turbulent flow for the reduction of milkborne pathogens. Foodborne Pathog. Dis. 2015, 12, 506-513. [CrossRef]

11. Krishnamurthy, K.; Demirci, A.; Irudayaraj, J. Inactivation of Staphylococcus aureus in milk using flow-through pulsed UV-light treatment system. J. Food Sci. 2007, 72, M233-M239. [CrossRef]

12. Christen, L.; Lai, C.T.; Hartmann, B.; Hartmann, P.E.; Geddes, D.T. The effect of UV-C pasteurization on bacteriostatic properties and immunological proteins of donor human milk. PLoS ONE 2013, 8, e85867. [CrossRef] [PubMed]

13. Bandla, S.; Choudhary, R.; Watson, D.G.; Haddock, J. Impact of UV-C processing of raw cow milk treated in a continuous flow coiled tube ultraviolet reactor. Agric. Eng. Int. CIGR J. 2012, 14, 86-93.

14. Gunter-Ward, D.M.; Patras, A.S.; Bhullar, M.; Kilonzo-Nthenge, A.; Pokharel, B.; Sasges, M. Efficacy of ultraviolet (UV-C) light in reducing foodborne pathogens and model viruses in skim milk. J. Food Process. Preserv. 2018, 42, e13485. [CrossRef]

15. Alberini, F.; Simmons, M.J.; Parker, D.; Koutchma, T. Validation of hydrodynamic and microbial inactivation models for UV-C treatment of milk in a swirl-tube 'SurePure Turbulator' ${ }^{\mathrm{TM}}$. J. Food Eng. 2015, 162, 63-69. [CrossRef]

16. Koutchma, T.; Bissonnette, S.; Popovic, V. An update on research, development and implementation of UV and pulsed light technologies for nonthermal preservation of milk and dairy products. Ref. Module Food Sci. 2019, 1-21.

17. Ansari, J.A.; Ismail, M.; Farid, M. Investigate the efficacy of UV pretreatment on thermal inactivation of Bacillus subtilis spores in different types of milk. Innov. Food Sci. Emerg. Technol. 2019, 52, 387-393. [CrossRef]

18. Martysiak-Żurowska, D.; Puta, M.; Kotarska, J.; Cybula, K.; Malinowska-Pańczyk, E.; Kołodziejska, I. The effect of UV-C irradiation on lipids and selected biologically active compounds in human milk. Int. Dairy J. 2017, 66, 42-48. [CrossRef]

19. Gayán, E.; Álvarez, I.; Condón, S. Inactivation of bacterial spores by UV-C light. Innov. Food Sci. Emerg. Technol. 2013, 19, 140-145. [CrossRef]

20. Peila, C.; Emmerik, N.E.; Giribaldi, M.; Stahl, B.; Ruitenberg, J.E.; Van Elburg, R.M.; Moro, G.E.; Bertino, E.; Coscia, A.; Cavallarin, L. Human milk processing: A systematic review of innovative techniques to ensure the safety and quality of donor milk. J. Pediatric Gastroenterol. Nutr. 2017, 64, 353-361. [CrossRef]

21. Weaver, G.; Bertino, E.; Gebauer, C.; Grovslien, A.; Mileusnic-Milenovic, R.; Arslanoglu, S.; Barnett, D.; Boquien, C.-Y.; Buffin, R.; Gaya, A. Recommendations for the establishment and operation of human milk banks in Europe: A consensus statement from the European Milk Bank Association (EMBA). Front. Pediatr. 2019, 7, 53. [CrossRef]

22. Geeraerd, A.; Valdramidis, V.; Van Impe, J. GInaFiT, a freeware tool to assess non-log-linear microbial survivor curves. Int. J. Food Microbiol. 2005, 102, 95-105. [CrossRef] [PubMed]

23. Bigelow, W.; Esty, J. The thermal death point in relation to time of typical thermophilic organisms. J. Infect. Dis. 1920, $27,602-617$. [CrossRef]

24. Mafart, P.; Couvert, O.; Gaillard, S.; Leguérinel, I. On calculating sterility in thermal preservation methods: Application of the Weibull frequency distribution model. Int. J. Food Microbiol. 2002, 72, 107-113. [CrossRef]

25. Coroller, L.; Leguérinel, I.; Mettler, E.; Savy, N.; Mafart, P. General model, based on two mixed Weibull distributions of bacterial resistance, for describing various shapes of inactivation curves. Appl. Environ. Microbiol. 2006, 72, 6493-6502. [CrossRef]

26. Cerf, O. A review tailing of survival curves of bacterial spores. J. Appl. Bacteriol. 1977, 42, 1-19. [CrossRef]

27. Gabriel, A.A.; Marquez, G.G.F. Inactivation behaviors of selected bacteria in ultraviolet-C-treated human breast milk. Innov. Food Sci. Emerg. Technol. 2017, 41, 216-223. [CrossRef]

28. Keyser, M.; Múller, I.A.; Cilliers, F.P.; Nel, W.; Gouws, P.A. Ultraviolet radiation as a non-thermal treatment for the inactivation of microorganisms in fruit juice. Innov. Food Sci. Emerg. Technol. 2008, 9, 348-354. [CrossRef] 
29. Fredericks, I.N.; Du Toit, M.; Krügel, M. Efficacy of ultraviolet radiation as an alternative technology to inactivate microorganisms in grape juices and wines. Food Microbiol. 2011, 28, 510-517. [CrossRef]

30. Lu, G.; Li, C.; Liu, P. UV inactivation of milk-related microorganisms with a novel electrodeless lamp apparatus. Eur. Food Res. Technol. 2011, 233, 79-87. [CrossRef]

31. Beauchamp, S.; Lacroix, M. Resistance of the genome of Escherichia coli and Listeria monocytogenes to irradiation evaluated by the induction of cyclobutane pyrimidine dimers and 6-4 photoproducts using gamma and UV-C radiations. Radiat. Phys. Chem. 2012, 81, 1193-1197. [CrossRef]

32. Cheigh, C.-I.; Park, M.-H.; Chung, M.-S.; Shin, J.-K.; Park, Y.-S. Comparison of intense pulsed light-and ultraviolet (UVC)-induced cell damage in Listeria monocytogenes and Escherichia coli O157: H7. Food Control 2012, 25, 654-659. [CrossRef]

33. Baysal, A.H. Short-wave ultraviolet light inactivation of pathogens in fruit juices. In Fruit Juices; Elsevier: Amsterdam, The Netherlands, 2018; pp. 463-510.

34. Possas, A.; Valero, A.; García-Gimeno, R.M.; Pérez-Rodríguez, F.; de Souza, P.M. Influence of temperature on the inactivation kinetics of Salmonella Enteritidis by the application of UV-C technology in soymilk. Food Control 2018, 94, 132-139. [CrossRef]

35. Keklik, N.M.; Demirci, A.; Puri, V.M.; Heinemann, P.H. Modeling the inactivation of Salmonella Typhimurium, Listeria monocytogenes, and Salmonella Enteritidis on poultry products exposed to pulsed UV light. J. Food Prot. 2012, 75, 281-288. [CrossRef] [PubMed]

36. Blázquez, E.; Rodríguez, C.; Ródenas, J.; Navarro, N.; Riquelme, C.; Rosell, R.; Campbell, J.; Crenshaw, J.; Segalés, J.; Pujols, J. Evaluation of the effectiveness of the SurePure Turbulator ultraviolet-C irradiation equipment on inactivation of different enveloped and non-enveloped viruses inoculated in commercially collected liquid animal plasma. PLoS ONE 2019, 14, e0212332. 